\title{
Measuring the Innovation of Economy throught Global and European Tools
}

\author{
Delia Marcela Pop ${ }^{1}$, Mircea Teodor Pop ${ }^{2}$ \\ ${ }^{1}$ University of Oradea, Industrial Engineering Department, Oradea, Romania \\ ${ }^{2}$ University of Oradea, Engineering and Management Department, Oradea, Romania
}

\begin{abstract}
Global and European innovation assessment and measurement represents a means by which relevant analyses of the innovative process can be carried out, as well as long-term strategies that aim at sustainable economic development. Measurement of innovation is carried out by specialized bodies through specialized studies, using relevant indicators whose number and definition have been modified over time as needed. This paper proposes a comparative analysis of the assessments of a country performances in innovation by means of a global measurement tool (Global Innovation Index) and of a European one (European Innovation Scoreboard).
\end{abstract}

\section{Introduction}

From life in caves to living in intelligent buildings, from wagon to today's cars and from the early 20th century industry up to the current industrial platforms, evolution is undeniable. The essence of this evolution is man, his intelligence, his creativity, his knowledge, his perseverance or his inventiveness, characteristics that are associated with him. Throughout this evolutionary process each moment has represented an innovation of the existing means or processes, and the creation of some totally new, based on totally unknown directions until that time.

In the current stage that mankind is going through, these moments of generating the novelty are defined, conceptualized, researched, monitored, even the process of innovation itself being continually subject to innovation. As a result, it is strictly timely and the management and measurement of innovation processes in companies, i.e. in the structures that assure the development of national economies and the global economy.

\section{Defining the concepts of innovation}

Innovation is the essence of the innovation process. Over time it has been defined in various forms that have also had specific evolution stages. Innovation is considered now as a challenge for industry, services, agriculture etc., but also for the economy in its whole, because innovation is seen as an essential element of competitiveness, as the essence of competitive development. From this perspective, it is increasingly accepted that only the achievement of results in research and technological development has become insufficient to increase competitiveness as they do not create a competitive economic outcome. It is necessary to transform the research results into innovative products and services that will generate a competitive advantage on the market. This is also the current strategic orientation of the European Union that aims at transforming Europe into an Innovation Union which, by stimulating competitiveness, targets the economic development and the quality of life of its citizens.

The conceptualization of innovation starts from defining it as a product or process that targets a marketable application of a novelty, an improvement or an invention. The innovation-related scientific research has deepened the basic knowledge and broadened the perspectives of addressing them. A consequence of this development is the formalization of science called the innovation management that has generated new innovation issues related to the following:

- the scientific foundation of the innovation process and its formal definition.

- the defining of business models by which the results of research and technological development are implemented through innovation in production.

- the emergence of so-called open innovation, i.e. the involvement of external collaborations in a company's innovation (R\&D - Research \& Development consortia, universities or research institutes, other companies in specific fields or specialists and communities involved in innovation by crowdsourcing) that have an essential role in generating new ideas or technologies, in the more efficient use of company assets or in finding and capitalizing of market-access opportunities even during the innovation cycle.

- improvement in the way innovation is managed. - development in the methods and tools of measuring innovation and its results. 
- modelling the innovation stimulation that addresses the process which the innovator has to follow in order to generate and stimulate innovation starting from a research result.

- the generating and developing of specific funding for innovation; in large firms that have their own innovatory processes the funding can be on projects, but in the case of SME's, funding opportunities extend to: grants, microcredits, business angels, venture capital firms, etc.

\section{The European Union's strategy for stimulating the innovation}

The European Union is a strong participant in the global process of research, technological development and innovation, being the main "knowledge factory" in the world. Thus, in June 2017, the World Intellectual Property Organization (WIPO), a specialized agency of the UN, published the top of the world's most innovative economies included in the Global Innovation Index[1]. The top three positions in the ranking list are held by European countries, of which the second (Sweden) and the third (Netherlands) are European Union countries. Also, the fifth place (UK) and the sixth one (Denmark) are held by EU countries. At the same time, in the top 25 of the most innovative countries in the world, 13 countries belong to the European Union. It has been determined that the community space supplies almost one-third of the scientific and technological production in the world.

But even being in this leadership position, the European Union is subject to strong international competitive pressures, especially from the emerging economies. At the same time, the aging phenomenon of the European population has a major effect on the economic growth of the area. In July 2017, EUROSTAT published a study on the impact of demographic aging in the European Union[2], according to which in 2050 the population aged over 65 will be of $28.5 \%$ compared to 2016 when this percentage was $19.2 \%$. As a result, the EU's economic strategy is geared towards the economic growth that can be achieved by stimulating research, technological development and innovation in particular. Innovation is the one that generates jobs and stimulates market competitiveness, elements that have a strong macro-economic growth effect.

In this direction, the European Union, "A Union of Innovation" - the EU's strategy of promoting this process, provides the framework for supporting an environment in which member countries encourage innovation in products, services and business models, including the public sector. This initiative is part of the European Union's growth strategy "Europe 2020" which predicts cumulative investment in research and innovation of 3\% of gross domestic product (GDP) by 2020[3]. One of the arguments in this guideline is linked to the fact that investments in research and innovation have a strong multiplier effect in the economy (every euro invested by the EU generates about 13 euros in terms of added value for businesses, meaning a significant multiplier of 13 times). As a result, Orizont 2020 is thought to be the European Union's largest research and innovation- oriented program that has a budget of $€ 80$ billion over the run-up period (2014-2020).

The aim of this major program to stimulate research and innovation is to support areas that are considered as priorities by the leaders of the European Union, which is reflected in seven challenges where specific investment in research and innovation can have a real impact for the benefit of European citizens. These societal challenges are: Health, demographic change and well-being, Food security, sustainable agriculture and forestry, bioeconomy and marine and maritime research, including inland waterways, Safe, environmentally friendly and efficient sources of energy, Intelligent, clean and integrated transport, Action to combat climate change, the environment, the efficient use of resources and raw materials, Europe in a changing world, Safe societies.

\section{Analyzing and measuring innovation}

Innovation is a very complex process whose analysis and macroeconomic management reveals the need to measure it. In order to be quantified, it has been used a number of instruments that group indicators specific to the fields of research - development and innovation. All these tools, at their impact on the real environment of research and innovation, have highlighted, following feed-backs, deficiencies that have been gradually corrected by successive improvements of the indicators used, the ways of collecting data, their processing, resulting reports etc.

Worldwide, one of the most widely used and accepted tools for measuring innovation is the Global Innovation Index. This is an annual report prepared and published by the World Intellectual Property Organization (WIPO), Cornell University (USA) and INSEAD (France)[1]. The analysis of innovation through the Global Innovation Index for 2017 was carried out within 127 functional economies and took into account 81 indicators that characterize global innovation, including the political environment, education, infrastructure, business sophistication, and so on. 2017 was the year when the study was entitled Innovation Feeding the World and was geared towards innovation in agriculture and food systems. This orientation has been given by the scientifically determined perspective according to which, at the global level, the earth's population will be of 9.7 billion in 2050, which will lead to a major increase in global food demand and significant pressure on the existing agricultural and food resources. From this perspective, the Index was oriented towards innovation as a means of supporting additional food demand but also as a solution for the sustainable finding and exploitation of food systems.

At the European Union level, the most significant tools for measuring innovation are:

- 1.The European Innovation Scoreboard (EIS) - is annually conceived by the European Commission, providing a comparative analysis of innovation performance in European Union countries, in other European countries as well as in neighbouring countries; with the help of this it assesses, on the basis of uniform criteria, the strengths and weaknesses of the national 
innovation systems; the latest European Innovation Scoreboard is the one corresponding to 2016 (published in June 2017) [4] and contains procedural changes that provide an easier way of tracking the performance of innovation over time, and through the new indicators it identifies the level of investment in skills, digital literacy, entrepreneurship and public-private partnerships; The pilot version of this assessment was published in 2000 and since 2001 complete analyses have been prepared and published under this name; In 2017, the methodology for analysis and measurement of performance in innovation contained 29 innovation indicators, divided into three main groups: a) Innovation drivers, b) Business activities and c) Results, and for a summary assessment of the national innovation performance, it is determined the Summary Innovation Index (SII), obtained as a single figure, by aggregating the indicators of the Table, for each country; the SII value varies between 0 (the lowest performance) and 1 (the highest performance); depending on each country's SII, there is an average performance index for innovation in EU countries, an average benchmark for each country's performance; according to this comparison, each country is framed within the following innovation performance groups: a) Leaders in innovation - whose performance exceeds the EU average by at least $20 \%$; b) Innovation followers - with performances below $10 \%$ of the average and up to $20 \%$ above the EU average; c) Moderate innovators - whose performances are below $10 \%$ of the European average but not more than $50 \%$ ) Modest innovators - with a performance index below $50 \%$ of the EU average.

- 2.The Community Innovation Survey (CIS) - is a statistical analysis based on the Oslo Manual methodology; this analysis is coordinated by the statistical office of the European Commission, EUROSTAT; the use of this analysis began in 1993 with CIS 1 Light; the evolution of this analysis is given in Table 1 .

Table 1. Community Innovation Survey (CIS).

\begin{tabular}{|l|l|l|l|l|l|l|l|l|l|l|}
\hline Indicators & $\begin{array}{l}\text { CIS 1 } \\
\text { Light }\end{array}$ & CIS 2 & CIS 3 & CIS 4 & $\begin{array}{l}\text { CIS } \\
2006\end{array}$ & $\begin{array}{l}\text { CIS } \\
2008\end{array}$ & $\begin{array}{l}\text { CIS } \\
2010\end{array}$ & $\begin{array}{l}\text { CIS } \\
2012\end{array}$ & $\begin{array}{l}\text { CIS } \\
2014\end{array}$ & $\begin{array}{l}\text { CIS } \\
2016\end{array}$ \\
\hline Analyzed period & 1993 & $\begin{array}{l}1997- \\
1998\end{array}$ & $\begin{array}{l}2000- \\
2001\end{array}$ & $\begin{array}{l}2002- \\
2004\end{array}$ & $\begin{array}{l}2004- \\
2006\end{array}$ & $\begin{array}{l}2006- \\
2008\end{array}$ & $\begin{array}{l}2008- \\
2010\end{array}$ & $\begin{array}{l}2010- \\
2012\end{array}$ & $\begin{array}{l}2012- \\
2014\end{array}$ & $\begin{array}{l}2014- \\
2016\end{array}$ \\
\hline $\begin{array}{l}\text { Total number of participant } \\
\text { countries of which }\end{array}$ & 18 & $18^{*}$ & $18^{* *}$ & 29 & 30 & 30 & 31 & 31 & 34 & $* * *$ \\
\hline UE member countries & 15 & 15 & 15 & 25 & 25 & 26 & 26 & 28 & 28 & $* * *$ \\
\hline
\end{tabular}

* except for Greece and Ireland that launched the survey in 1999

** except for Norway, Iceland, Luxembourg and Greece that launched the survey in 2002

$* * *$ at the time of writing, the final results have not yet been published by EUROSTAT

- 3.The European Trend Chart on Innovation in Europe is a tool that analyzes innovation in Europe, introduced by the European Commission in 1998 to monitor changes in Member States' innovation policies; under this name was used until 2002.

- 4.Inno-Barometer - is an annual European-level research carried out by the European Commission, which focuses on the activities and attitudes of European countries towards innovation, also establishing trends in firms; starting with 2015 , the research has been conducted by means of a sample survey based on a questionnaire mainly observing the way in which companies manage their innovation activities, plan their investments for modernization, pursue the results of innovation, and determine the barriers that limit the marketing of innovative products and services.

\section{Comparative use of global and European innovation measurement tools}

For a comparative analysis of innovation performance of a country in the European Union at global and European level, two studies were carried out annually, namely: the Global Innovation Index (for Global Analysis) and the Scoreboard European (for country analysis at European level), only the analysis for the countries of the European
Union. Romania was used as a country, and the evolution in innovation for 2010-2017 was pursued.

Romania analyzed in terms of the Global Innovation Index in 2017 ranks 42th out of the 127 analyzed economies. The performance of the evaluated economies was determined by a set of 81 indicators distributed into the following groups: institutions, business and political environment, regulatory framework, education, R \& D, human capital and infrastructure. The evolution of Romania's position in this ranking since 2010 can be found in Table 2.

Analyzing the data above, it can be noticed that Romania holds, in the analyzed period, the positions between 40 and 55, which means that it is in the first half of the ranking.

But, however, Romania's position is inferior to many countries in the region such as the Czech Republic, Poland, Bulgaria, Slovenia etc. Romania's position was followed, most of the years, by Greece, Turkey, Russia etc., countries considered to have an economic power superior to Romania.

At the same time, over the entire period, Romania's performance is more than $55 \%$ of that of the leader, being, in 2010, at almost two-thirds of this.

By conducting an analysis of innovation in Romania through the European Innovation Scoreboard (EIS) for the period similar to the previous analysis but within the European Union, a centralization of the data in Table 3. 
Table 2 - The evolution of Romania's position in the Global Innovation Index between 2010 and 2017.

\begin{tabular}{|l|c|c|c|c|c|c|c|c|}
\hline Indicators & 2010 & 2011 & 2012 & 2013 & 2014 & 2015 & 2016 & 2017 \\
\hline $\begin{array}{l}\text { Number of } \\
\text { analyzed } \\
\text { economies }\end{array}$ & 132 & 125 & 141 & 142 & 143 & 141 & 128 & 127 \\
\hline $\begin{array}{l}\text { Number of } \\
\text { indicators used }\end{array}$ & 60 & 60 & 84 & 84 & 81 & 80 & 82 & 81 \\
\hline $\begin{array}{l}\text { Leader of } \\
\text { classification }\end{array}$ & Iceland & Switzerland & Switzerland & Switzerland & Switzerland & Switzerland & Switzerland & Switzerland \\
\hline Leader's score & 4,86 & 63,82 & 68,20 & 66,65 & 64,78 & 68,30 & 66,28 & 67,69 \\
\hline $\begin{array}{l}\text { Position of } \\
\text { Romania }\end{array}$ & 52 & 50 & 52 & 40 & 55 & 54 & 48 & 42 \\
\hline $\begin{array}{l}\text { Score of } \\
\text { România }\end{array}$ & 3,22 & 36,83 & 37,80 & 37,84 & 38,08 & 38,20 & 37,90 & 39,16 \\
\hline $\begin{array}{l}\text { Average score } \\
\text { of Romania }\end{array}$ & 66 & 58 & 55 & 57 & 59 & 56 & 57 & 58 \\
\hline
\end{tabular}

Table 3 - Evolution of Romania's position in the European Scoreboard between 2010 and 2017.

\begin{tabular}{|c|c|c|c|c|c|c|c|c|}
\hline Indicators & 2010 & 2011 & 2012 & 2013 & 2014 & 2015 & 2016 & 2017 \\
\hline $\begin{array}{l}\text { Number of analyzed } \\
\text { economies }\end{array}$ & 27 & 27 & 27 & 27 & 28 & 28 & 28 & 28 \\
\hline Number of indicators used & 25 & 25 & 24 & 24 & 25 & 25 & 25 & 27 \\
\hline Leader of classification & Sweden & Sweden & Sweden & Sweden & Sweden & Sweden & Sweden & Sweden \\
\hline Position of Romania & 24 & 24 & 25 & 26 & 26 & 28 & 28 & 28 \\
\hline Type of innovator & Modest & Modest & Modest & Modest & Modest & Modest & Modest & Modest \\
\hline $\begin{array}{l}\text { Number of countries below } \\
\text { the average of performance } \\
\text { in EU }\end{array}$ & 16 & 16 & 16 & 16 & 17 & 17 & 17 & 17 \\
\hline
\end{tabular}

The graph shows that Sweden is still the European leader in innovation, being followed by Denmark and Finland. Romania maintains the last position, being considered a modest Innovator throughout the analyzed period. Since 2016, in the European Union there are only two countries with a modest Innovation state, most of the European countries being moderate innovators.

\section{Conclusions}

By the two studies: the Global Innovation Scoreboard and the European Innovation Scoreboard, it results the fact that the performances in innovation is an indicator that needs to be constantly pursued and refined. The global innovation measurement system is based on a larger number of indicators and manages a significantly larger number of countries participating in the research. Both systems have a special complexity, as well as different but relevant indicators and methodologies. By linking these studies and the results of the other innovation measurement tools described in the paper, Europe is still a pole of scientific research and technological development but it is exceeded by the United States, Singapore and Korea in terms of performance in marketing products and services resulting from innovation.

Another issue arising from the overlapping of the two surveys is that all EU countries are ranked in the Global Index to position 44, which is the first third of the ranking. The EU leader, Sweden, is ranked second in the Global Index, the first being a European country but not in the EU. This demonstrates, in both systems of assessing the innovation, the superiority of the European Union from the perspective of innovative processes.

As far as Romania is concerned, it is worth mentioning that for the year 2017 in the global ranking Romania is ranked 42th but it is the penultimate country in the European Union, while Greece is ranked 44th. This positioning reflects the fact that Romania as a member of the European Union has confirmed its position as modest Innovator and the Global Index of Innovation, but it is in the first third of this world ranking, because the European performances in innovation at the global level are superior.

\section{References}

1. The Global Innovation Index 2017. Innovation Feeding the World, Cornell University, INSEAD, and WIPO, XVIII -XIX, (2017)

2. http://ec.europa.eu/eurostat/statisticsexplained/index.php/Population_structure_and_ageing

3. https://ec.europa.eu/programmes/horizon2020/what -horizon-2020 
4. http://ec.europa.eu/growth/industry/innovation/fact s-figures/scoreboards_ro 